\title{
EVALUATING THE ECONOMIC OUTCOMES OF THE POLICY OF FEE EXEMPTION FOR MATERNAL DELIVERY CARE IN GHANA
}

\author{
"F.A. ASANTE ${ }^{1}$, C. CHIKWAMA ${ }^{2}$, ABA DANIELS ${ }^{3}$, and MARGARET ARMAR- \\ KLEMESU $^{3}$ \\ Institute of Statistical, Social \& Economic Research (ISSER), University of Ghana, Legon, ${ }^{2}$ Immpact, \\ University of Aberdeen, Foresterhill Campus, Westburn Road, Aberdeen AB25 5ZY, Scotland, \\ United Kingdom, ${ }^{3}$ Immpact, Noguchi Memorial Institute for Medical Research (NMIMR), Univer- \\ sity of Ghana, Legon, Ghana
}

\section{SUMMARY}

Background: The Government of Ghana's fee exemption policy for delivery care introduced in September 2003, aimed at reducing financial barriers to using maternal services. This policy also aimed to increase the rate of skilled attendance at delivery, reduce maternal and perinatal mortality rates and contribute to reducing poverty.

Objective: To evaluate the economic outcomes of the policy on households in Ghana.

Methods: Central and Volta regions were selected for the study. In each region, six districts were selected. A two stage sampling approach was used to identify women for a household cost survey. A sample of 1500 women in Volta region (made up of 750 women each before and after the exemption policy) and 750 women after the policy was introduced in Central region.

Outcome Measures: Household out-of-pocket payment for maternal delivery and catastrophic out-of-pocket health payments.

Results: There was a statistically significant decrease in the mean out-of-pocket payments for caesarean section (CS) and normal delivery at health facilities after the introduction of the policy. The percentage decrease was highest for CS at $28.40 \%$ followed by normal delivery at $25.80 \%$. The incidence of catastrophic out-of-pocket payments also fell. At lower thresholds, the incidence of catastrophic delivery payment was concentrated more amongst the poor. For the poorest group $\left(1^{\text {st }}\right.$ quintile) household out-of-pocket payments in excess of $2.5 \%$ of their pre-payment income dropped from $54.54 \%$ of the households to $46.38 \%$ after the exemption policy. The policy had a more positive impact on the extreme poor than the poor.
The richest households ( $5^{\text {th }}$ quintile) had a decline in out-of-pocket payments of $21.51 \%$ while the poor households ( $1^{\text {st }}$ quintile) had a $13.18 \%$ decline.

Conclusions: The policy was beneficial to users of the service. However, the rich benefited more than the poor. There is need for proper targeting to identify the poorest of the poor before policies are implemented to ensure maximum benefit by the target group.

Keywords: Fee Exemption Policy, Maternal Delivery Care, Catastrophic out-of-Pocket Payments, Out-of-Pocket Payments.

\section{INTRODUCTION}

The lifetime risk of maternal death in the least developed countries is estimated to be greater than 1 in 10 , while for the most developed countries it is about 1 in $8,000^{1}$. Institutional data indicates that Ghana has persistently unacceptable high maternal mortality ratios, estimated to range from 214 to 800 per 100,000 live births ${ }^{2}$.

In September 2003, the Government of Ghana introduced the policy of exempting users of maternity services from delivery fees in the four most deprived regions of the country, which are Central, Northern, Upper West and Upper East Regions. The policy was later extended to the remaining six regions of Ghana in April 2005 with the aim of reducing financial barriers to using delivery services. The prospect was that it would lead to an increase in rate of skilled attendance at delivery and consequently to a reduction in maternal and

*Author for correspondence

fasante@ug.edu.gh 
perinatal mortality rates, and also contribute to poverty reduction ${ }^{3}$.

So far, comparatively little progress has been made globally, stimulating donors and governments to look for cost-effective and sustainable approaches which can reduce maternal mortality. This is in the light of the fact that one of the Millennium Development Goals is to reduce maternal mortality by three-quarters by $2015^{4}$.

Increasing the proportion of women who deliver with a skilled attendant remains one of the main challenges and is a key component of the Safe Motherhood Initiative ${ }^{5}$. Ghana has had a persistently high maternal mortality rate, growing social inequalities, and rates of skilled attendance being either stagnant or declining for poorer women ${ }^{6}$. Financial barriers are one of the most important factors or constraints to seeking skilled care during deliveries. In general, delivery costs tend to be lumpy and may sometimes go up as much as 8 times a household's monthly income ${ }^{7}$. The fee exemption policy, by reducing these costs, may play a very important role in increasing the rates of skilled attendance and protecting households from making catastrophic payments for maternal delivery and consequently from falling into poverty.

In order to secure sustainability of the fee exemption policy in Ghana, the Ministry of Health established a tariff which set reimbursement rates according to the type of delivery and the facility type $^{3}$. The institutional arrangement stipulates that both the funds and the implementation of the policy are decentralised to the district level and involve close collaboration between the health sector and the District Assemblies, which act as the fund manager. The health institution grants the exemptions, and the district health administration acts as the bridge between the health institutions and the District Assemblies in the reimbursement of health institutions.

Access to health services for the poor and vulnerable in Ghana has been a problem since the introduction of user fees in the mid-1980s. The original objective of the user fees policy was to raise revenue and to deter frivolous use of scarce resources in the health sector. However, recognising that some people could not afford health services, an exemption policy for specified categories of the poor was introduced. The experience to date shows that Ghana has not been able to formulate an efficient exemption mechanism targeted to the poor ${ }^{8,9}$.
Healthcare payments affect available resources by reducing the share of income available to be spent on other consumption goods, which may lead to poverty when they turn out to be excessive in comparison to households' income ${ }^{10-12}$. By protecting households from such effects of health care payments, the fee exemption policy also contributes to other social goals, in particular poverty reduction.

The important questions with regards to the fee exemption policy for delivery care in Ghana are therefore often expressed on the subject of healthcare payments and poverty. The main objective of the study was to evaluate the economic outcomes of the policy of fee exemption for delivery care on households in Ghana. The specific objectives were:

- To measure the impact of the exemption policy on households' cost of maternal delivery care.

- To examine the distribution of the share of households' out-of-pocket payments in household total income across poverty groups; that is, to what extent does the fee exemption policy protect households from making "catastrophic" out-of-pocket payments across poverty groups; and

- To examine the distribution of households' out-of-pocket payments for delivery care in the periods before and after the introduction of the fee exemption policy.

\section{SUBJECT AND METHODS \\ Study Area}

Central and Volta regions were selected for the study based on the following reasons: (i) the policy of fee exemption was applied to both regions at different times, with a 19 month gap, thus providing an opportunity to investigate time trends. Central region was among the first four regions (one of the poorest regions in Ghana) to introduce the policy, with district-level implementation starting between August 2003 and April 2004. In April 2005 , the policy was extended to all regions in Ghana, including the Volta region; and (ii) both regions comprise districts that have similar socioeconomic profiles and can be matched on the basis of presence of a hospital, poverty status, size of the population and urban profile. Six districts were selected in each region.

\section{Study Design Sampling Procedure}

A household costs survey comprising women who delivered in the 18 months leading to the survey 
was conducted. In order to identify women in the sampling frame, routine immunisation systems in health facilities, child welfare clinics as well as community outreach immunisation programmes were used. The sampling frame consisted of women who had one of the following forms of delivery: (i) vaginal delivery at a health facility; (ii) vaginal delivery at home or with a Traditional Birth Attendant (TBA); and (iii) a caesarean section.

\section{Sample Size}

Based on delivery costs estimates in Borghi et al. $^{13}$, the sample size for the study was calculated in order to test the null-hypothesis that the introduction of the fee exemption policy would significantly lower costs to the household. It was estimated that the study would require a sample of 300 women who had a vaginal delivery in health facilities (both normal vaginal deliveries and those assisted by instruments), 300 who have had vaginal delivery in their homes or with TBAs, and 150 women who have had a caesarean section, all before and after the introduction of fee exemption. In all a sample of 1500 women in Volta region and 750 women in Central region (see Table 1) was attempted. For the study, all deliveries before $31^{\text {st }}$ April 2005 were classified as having taken place before the fee exemption policy whiles deliveries from $1^{\text {st }}$ May 2005 was classified as period after the fee exemption policy.

Table 1 Sample Size for Household Cost Survey

\begin{tabular}{lcc} 
& $\begin{array}{c}\text { Volta } \\
\text { Region }\end{array}$ & $\begin{array}{c}\text { Central } \\
\text { Region }\end{array}$ \\
\hline Vaginal Delivery HF & 300 & - \\
Vaginal delivery H/TBA & 300 & - \\
C Section & 150 & - \\
Total & $\mathbf{7 5 0}$ & - \\
Vaginal Delivery HF & 300 & 300 \\
Vaginal Delivery H/TBA & 300 & 300 \\
C Section & 150 & 150 \\
Total & $\mathbf{7 5 0}$ & $\mathbf{7 5 0}$ \\
\hline & $\mathbf{1 5 0 0}$ & $\mathbf{7 5 0}$ \\
\hline
\end{tabular}

A two-stage approach was used to identify women for the household cost survey. The first stage selected health facilities operating immunisation programmes and child welfare clinics in all the six districts identified for the evaluation in Central and Volta regions and sampled women falling into the sampling frame. In the second stage the sampled women were followed to their homes to administer the household cost questionnaire.

\section{Method of Analysis}

\section{Cost of Maternal Delivery Care to Households}

The costs of maternal delivery care to the household are defined as individuals' or households' out-of-pocket payments associated with the delivery. The individuals or households out-of-pocket payments for maternal delivery care are made up of the following: (a) payment to the delivery service provider - for the delivery service, drugs and supplies and inpatient stay; (b) items purchased outside the facility for delivery; (c) transportation cost to and from place of delivery; (d) amount spent on gifts to person(s) assisting in delivery; and (e) other cost items not listed above but made in the course of delivery at the service provider.

These cost can be categorised as direct and indirect cost and expressed as $\mathrm{C}=\mathrm{X}+\mathrm{Y}$, where $\mathrm{C}=$ individual or household out-of-pocket payment for maternal delivery care, $\mathrm{X}=$ direct cost associated with maternal delivery care, that is (a) and (b) above; $\mathrm{Y}=$ indirect costs, that is (c), (d) and (e) above.

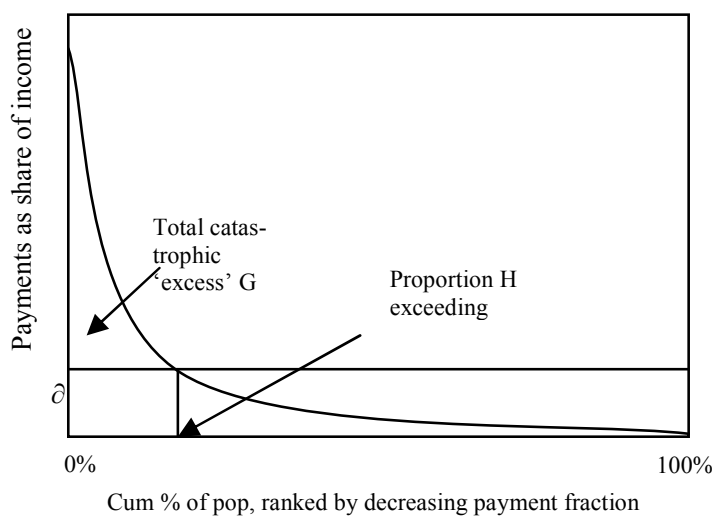

Figure 1 Catastrophic payments as share of pre-payment income by cumulative percent of population, ranked by decreasing payment fraction.

\section{Catastrophic Health Care Payments}

One way to measure the extent to which a given sample of individuals has been exposed to catastrophic expenses is the number (or proportion) of individuals whose health care costs as a proportion of income exceed the threshold. Figure 1 shows the cumulative share of the sample, ordered by the ratio of out-of-pocket payment for maternal delivery care to pre-payment income, beginning with individuals or households with the largest ratio. At a threshold of $\partial$, one obtains the proportion $\mathrm{H}$ of the sample whose expenditures as a proportion of their income exceed the threshold $\partial$. This is the catastrophic payment headcount. Households thus 
have at least $(1-\partial)$ of their income to spend on things other than maternal delivery care.

The second approach is based on comparing households' pre-payment and post-payment incomes relative to some income threshold, below which a household would be regarded as poor (see figure 2). In this study we use the Ghana poverty lines, $Z_{\mathrm{pov}}$ to set these income thresholds. The principle underlying this analysis is that health care payments should not push households into poverty or worsen their poverty status.

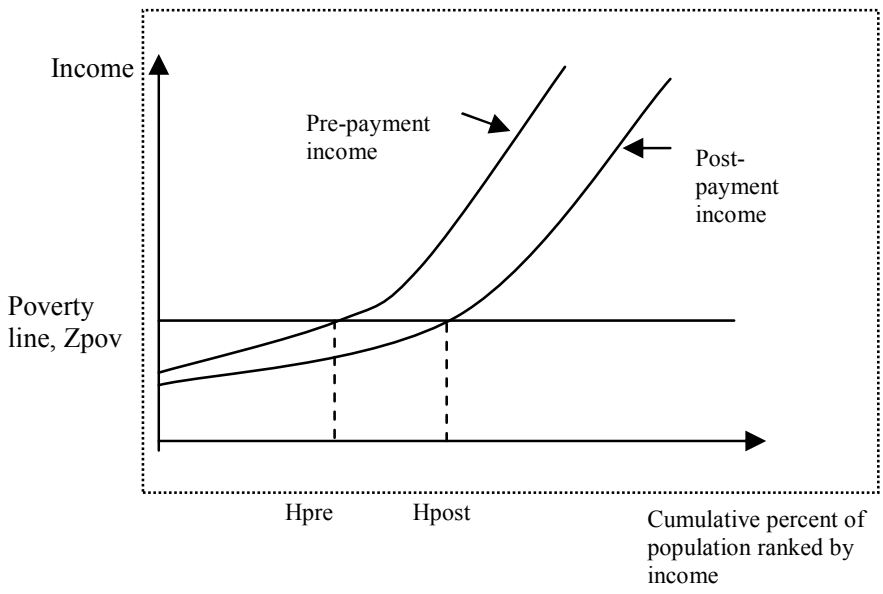

Figure 2 Head count poverty impact on health payments

Figure 2 provides a simple framework for examining the impact of out-of-pocket payments on a basic measure of poverty - the headcount. The figure plots income before and after out-of-pocket payments (pre-payment and post-payment income, respectively) along the y-axis against the cumulative percentage of individuals ranked by prepayment income along the $\mathrm{x}$-axis. The point on the $\mathrm{x}$-axis where the curve crosses the poverty line $\left(\mathrm{HC}_{\mathrm{pre}}\right)$ gives the fraction of people living in poverty "before" healthcare payments. This is called the (pre-payment) poverty headcount ratio.

After deducting household payments for delivery care, a new income, post payment income $\left(\mathrm{HC}_{\mathrm{post}}\right)$ is obtained. The poverty headcount increase equals the distance on the $\mathrm{x}$-axis between $\mathrm{HC}_{\mathrm{pre}}$ and $\mathrm{HC}_{\text {post }}$.

The study adopted the two approaches, the first to assess the extent to which the fee exemption policy protects households from making catastrophic payments and the second approach to assess the extent to which fee exemption policy protected households from the impoverishing effects of health care payments.

\section{Financing Maternal Delivery Care by House- holds}

Equity in maternal delivery care financing raises a lot of issues. Some of the issues are as follows: Who pays for maternal delivery care? To what extent are payments towards maternal delivery care related to ability to pay? Is the relationship proportional? Or is it progressive; do maternal delivery care payments account for an increasing proportion of ability to pay (ATP) as the latter rises? Or, is there a regressive relationship, in the sense that payments comprise a decreasing share of ATP? The policymaker's preferred relationship between maternal delivery care payments and ATP will vary with his or her conception of fairness, but quantification of the relationship is of interest from a wide range of equity perspectives.

\section{RESULTS}

Table 2 shows the sample composition by place and type of delivery for women in the sample who delivered before and after introduction of the policy of fee exemptions. There was a fall in home/TBA deliveries and normal deliveries at health facilities from $42.7 \%$ to $40.3 \%$ and $47.8 \%$ to $45.3 \%$, respectively. With c-sections, there was an increase from $9.6 \%$ to $14.5 \%$.

Table 2 Type of Delivery Before/After Fee Exemption Policy

\begin{tabular}{|c|c|c|}
\hline \multirow[b]{2}{*}{ Type } & \multicolumn{2}{|c|}{ Fee Exemption Policy } \\
\hline & Before & After \\
\hline Home/TBA & 42.7 & 40.3 \\
\hline Caesarean section & 9.6 & 14.5 \\
\hline $\begin{array}{l}\text { Normal delivery at } \\
\text { health facility }\end{array}$ & 47.8 & 45.3 \\
\hline
\end{tabular}

Source: Computed from survey data

Cost of Maternal Delivery Care to Households The percentage decrease in delivery fees was highest for c-sections at $28.4 \%$ followed by normal delivery at health facility $(25.8 \%)$ and home/TBA delivery (13.7\%). A similar pattern was also observed for total payment for delivery care. The total payment for c-section fell by $21.6 \%$; normal deliveries in health facilities by $18.9 \%$ and home/TBAs, $7.6 \%$ (Table 3).

The share of mean households' out-of-pocket payment for delivery (delivery fee at the facility) in total payment for delivery care declined after the exemption policy. The percentage point change in decline was more for caesarean section delivery 
Table 3 Mean Out-Of-Pocket Payment for Delivery Care before /after policy (thousands of cedis)

\begin{tabular}{|c|c|c|c|c|c|c|c|c|}
\hline \multirow[b]{2}{*}{ Type of Delivery } & \multicolumn{4}{|c|}{ Delivery Fees } & \multicolumn{4}{|c|}{ Total Payments for Deliveries } \\
\hline & Before & After & $\begin{array}{c}\text { Percentage } \\
\text { Change }\end{array}$ & $\begin{array}{c}\text { t-value } \\
{[P(T>t)]}\end{array}$ & Before & After & $\begin{array}{c}\text { Percentage } \\
\text { Change }\end{array}$ & $\begin{array}{c}\text { t-value } \\
{[P(T>t)]}\end{array}$ \\
\hline Home/TBA & 62.0 & 53,4 & 13.7 & $\begin{array}{l}1.1428 \\
{[0.1267]}\end{array}$ & 203.9 & 186,4 & 7.6 & $\begin{array}{l}1.2258 \\
{[0.1103]}\end{array}$ \\
\hline Caesarean Section & $1,396.5$ & 999.6 & 28.4 & $\begin{array}{l}2.7314 \\
{[0.0034]}\end{array}$ & $1,755.7$ & $1,375.5$ & 21.6 & $\begin{array}{l}2.3308 \\
{[0.0102]}\end{array}$ \\
\hline $\begin{array}{l}\text { Normal Delivery } \\
\text { at Health Facility }\end{array}$ & 152.1 & 112.8 & 25.8 & $\begin{array}{l}3.2529 \\
{[0.0006]}\end{array}$ & 378.5 & 306.7 & 18.9 & $\begin{array}{l}2.8632 \\
{[0.0021]}\end{array}$ \\
\hline
\end{tabular}

than normal deliveries at health facilities (Table 4$). \quad$ For the poorest $\left(1^{\text {st }}\right.$ quintile) group, before the ex-

Table 4 Mean households' out-of-pocket payments for maternal delivery (before and after exemption) (thousand of cedis)

\begin{tabular}{|c|c|c|c|c|c|c|c|c|c|}
\hline \multirow[b]{3}{*}{$\begin{array}{l}\text { Type of } \\
\text { Delivery }\end{array}$} & \multicolumn{6}{|c|}{ Volta } & \multirow{2}{*}{\multicolumn{3}{|c|}{$\begin{array}{c}\text { Central } \\
\text { After }\end{array}$}} \\
\hline & \multicolumn{3}{|c|}{ Before } & \multicolumn{3}{|c|}{ After } & & & \\
\hline & $\begin{array}{l}\text { Delivery } \\
\text { Pay- } \\
\text { ments } \\
\text { To } \\
\text { Health } \\
\text { Facility } \\
\end{array}$ & $\begin{array}{l}\text { Total } \\
\text { Pay- } \\
\text { ments } \\
\text { For De- } \\
\text { livery }\end{array}$ & $\begin{array}{l}\text { Ratio of } \\
\text { Facility } \\
\text { Payment } \\
\text { In Total }\end{array}$ & $\begin{array}{l}\text { Delivery } \\
\text { Pay- } \\
\text { ments } \\
\text { To } \\
\text { Health } \\
\text { Facility } \\
\end{array}$ & $\begin{array}{l}\text { Total } \\
\text { Pay- } \\
\text { ments } \\
\text { For De- } \\
\text { livery }\end{array}$ & $\begin{array}{l}\text { Ratio of } \\
\text { Facility } \\
\text { Payment } \\
\text { In Total }\end{array}$ & $\begin{array}{l}\text { Delivery } \\
\text { Pay- } \\
\text { ments } \\
\text { To } \\
\text { Health } \\
\text { Facility } \\
\end{array}$ & $\begin{array}{l}\text { Total } \\
\text { Pay- } \\
\text { ments } \\
\text { For De- } \\
\text { livery }\end{array}$ & $\begin{array}{l}\text { Ratio of } \\
\text { Health } \\
\text { Facility } \\
\text { Payment } \\
\text { In Total }\end{array}$ \\
\hline Home/TBA & 64.0 & 210.8 & 30.33 & 51.2 & 194.10 & 26.37 & 56.4 & 176.4 & 31.94 \\
\hline $\begin{array}{l}\text { Caesarean } \\
\text { Section }\end{array}$ & $1,725.5$ & $2,119.0$ & 81.43 & 772.9 & $1,189.0$ & 64.97 & $1,198.4$ & $1,538.5$ & 77.89 \\
\hline $\begin{array}{l}\text { Normal De- } \\
\text { livery } \\
\text { at Health } \\
\text { Facility }^{1}\end{array}$ & 172.6 & 404.7 & 42.65 & 110.8 & 329.6 & 33.67 & 116.0 & 267.5 & 43.44 \\
\hline Combined & 274.5 & 485.6 & 56.53 & 164.6 & 376.6 & 43.70 & 290.5 & 463.6 & 62.65 \\
\hline
\end{tabular}

Source: Computed from survey data

A similar pattern is also observed in the mean share of delivery fee in total out-of-pocket payment for delivery (Table 5). The mean share of delivery fee in delivery payment to facility at home/TBA slightly increased in the Volta region after the fee exemption policy.

Catastrophic and Impoverishment in Paying for Maternal Delivery Care

The distribution of catastrophic out-of-pocket payment shows a fall after the exemption policy. emption policy, $54.54 \%$ of the households recorded out-of-pocket payments in excess of $2.5 \%$ of their pre-payment income. This fell to $46.38 \%$ of households after the exemption policy. The trend follows a similar pattern from the poor to the rich as the threshold level increases (Table 6).

Adjusting the poverty lines of 1999 of 700,000 cedis (extreme poor) and 900,000 cedis (poor) to 2005 prices, payments for maternal deliveries increase the poverty head count by 1.3 percentage 
Table 5 Mean Households' out-of-pocket Payments for Delivery Fee (before and after exemption) (thousand of cedis)

\begin{tabular}{|c|c|c|c|c|c|c|c|c|c|}
\hline \multirow[b]{3}{*}{$\begin{array}{l}\text { Type of De- } \\
\text { livery }\end{array}$} & \multicolumn{6}{|c|}{ Volta } & \multirow{2}{*}{\multicolumn{3}{|c|}{$\begin{array}{c}\text { Central } \\
\text { After }\end{array}$}} \\
\hline & \multicolumn{3}{|c|}{ Before } & \multicolumn{3}{|c|}{ After } & & & \\
\hline & $\begin{array}{l}\text { Deliv- } \\
\text { ery } \\
\text { Fee }\end{array}$ & $\begin{array}{l}\text { Deliv- } \\
\text { ery } \\
\text { Pay- } \\
\text { ments } \\
\text { to Fa- } \\
\text { cility }\end{array}$ & $\begin{array}{l}\text { Ratio of } \\
\text { Delivery } \\
\text { Fee - De- } \\
\text { livery } \\
\text { Payment } \\
\text { to Health } \\
\text { Facility } \\
\end{array}$ & $\begin{array}{l}\text { Deliv- } \\
\text { ery } \\
\text { Fee }\end{array}$ & $\begin{array}{l}\text { Delivery } \\
\text { Pay- } \\
\text { ments to } \\
\text { Facility }\end{array}$ & $\begin{array}{l}\text { Ratio of } \\
\text { Delivery } \\
\text { Fee - De- } \\
\text { livery } \\
\text { Payment } \\
\text { to Health } \\
\text { Facility } \\
\end{array}$ & $\begin{array}{l}\text { Deliv- } \\
\text { ery } \\
\text { Fee }\end{array}$ & $\begin{array}{l}\text { Deliv- } \\
\text { ery } \\
\text { Pay- } \\
\text { ments } \\
\text { to Fa- } \\
\text { cility }\end{array}$ & $\begin{array}{l}\text { Ratio of } \\
\text { Delivery } \\
\text { Fee - Deliv- } \\
\text { ery Payment } \\
\text { to Health } \\
\text { Facility }\end{array}$ \\
\hline Home/TBA & 52.5 & 64.0 & 82.00 & 52.2 & 51.2 & 101.95 & 52.2 & 56.4 & 92.70 \\
\hline $\begin{array}{l}\text { Caesarean } \\
\text { Section }\end{array}$ & $1,133.3$ & $1,725.5$ & 65.66 & 273.5 & 772.9 & 35.38 & 255.0 & $1,198.4$ & 21.28 \\
\hline $\begin{array}{l}\text { Normal De- } \\
\text { livery } \\
\text { at Health } \\
\text { Facility }\end{array}$ & 136.6 & 172.6 & 79.14 & 63.4 & 110.9 & 57.11 & 56.6 & 116.0 & 48.81 \\
\hline Combined & 166.5 & 274.5 & 60.65 & 82.8 & 164.6 & 50.32 & 55.2 & 290.5 & 18.99 \\
\hline
\end{tabular}

Table 6 Distribution of the catastrophic out-of-pocket payment head-count by expenditure quintile

\begin{tabular}{|c|c|c|c|c|c|r|r|r|r|}
\hline \multirow{2}{*}{ Quintile } & \multicolumn{3}{|c|}{$\begin{array}{c}\text { Combined } \\
\text { (Threshold) }\end{array}$} & \multicolumn{3}{c|}{$\begin{array}{c}\text { Before exemption } \\
\text { (Threshold) }\end{array}$} & \multicolumn{3}{c|}{$\begin{array}{c}\text { After Exemption } \\
\text { (Threshold) }\end{array}$} \\
\cline { 2 - 11 } & $\mathbf{2 . 5 \%}$ & $\mathbf{5 . 0 \%}$ & $\mathbf{1 0 . 0 \%}$ & $\mathbf{2 . 5 \%}$ & $\mathbf{5 . 0 \%}$ & $\mathbf{1 0 . 0 \%}$ & $\mathbf{2 . 5 \%}$ & $\mathbf{5 . 0 \%}$ & $\mathbf{1 0 . 0 \%}$ \\
\hline 1 & 48.55 & 20.94 & 9.8 & 54.54 & 23.78 & 10.48 & 46.38 & 19.74 & 9.21 \\
\hline 2 & 30.51 & 11.35 & 4.0 & 33.57 & 12.59 & 4.20 & 28.19 & 9.83 & 3.60 \\
\hline 3 & 31.11 & 13.78 & 4.7 & 33.79 & 16.55 & 4.83 & 29.70 & 12.87 & 4.62 \\
\hline 4 & 29.84 & 13.36 & 4.9 & 29.07 & 12.06 & 4.96 & 31.47 & 14.75 & 5.24 \\
\hline 5 & 33.18 & 14.25 & 6.7 & 35.66 & 15.38 & 9.79 & 31.02 & 13.20 & 4.95 \\
\hline
\end{tabular}

Source: Computed from survey data

points before the exemption policy (Table 7). After the fee exemption policy, payments for maternal delivery increase the poverty head count by 2.2 percentage points. The fee exemption policy thus

Table 7 Poverty Head count and the fee exemption policy

\begin{tabular}{|c|c|c|c|c|c|c|c|}
\hline & \multicolumn{3}{|c|}{ Before Exemption } & & \multicolumn{3}{|c|}{ After Exemption } \\
\hline & $\begin{array}{l}\text { Pre- } \\
\text { payment } \\
\text { Poverty } \\
\text { Head } \\
\text { Count } \\
\end{array}$ & $\begin{array}{l}\text { Post- } \\
\text { payment } \\
\text { Poverty } \\
\text { Head Count }\end{array}$ & $\begin{array}{l}\text { Poverty } \\
\text { Head- } \\
\text { count } \\
\text { Impact }\end{array}$ & & $\begin{array}{l}\text { Pre- } \\
\text { payment } \\
\text { Poverty } \\
\text { Head Count }\end{array}$ & $\begin{array}{l}\text { Post- } \\
\text { payment } \\
\text { Poverty } \\
\text { Head } \\
\text { Count } \\
\end{array}$ & $\begin{array}{l}\text { Headcount } \\
\text { Poverty } \\
\text { Impact }\end{array}$ \\
\hline \multicolumn{8}{|c|}{ REGIONS COMBINED } \\
\hline Poor & 56.6 & 57.9 & 1.3 & Poor & 56.3 & 58.5 & 2.2 \\
\hline $\begin{array}{l}\text { Extreme } \\
\text { Poor }\end{array}$ & 40.2 & 42.7 & 2.5 & $\begin{array}{l}\text { Extreme } \\
\text { Poor }\end{array}$ & 39.3 & 40.6 & 1.3 \\
\hline \multicolumn{8}{|c|}{ VOLTA REGION } \\
\hline Poor & 58 & 59.2 & 1.2 & Poor & 57.9 & 60 & 2.1 \\
\hline $\begin{array}{l}\text { Extreme } \\
\text { Poor }\end{array}$ & 41.8 & 44 & 2.2 & $\begin{array}{l}\text { Extreme } \\
\text { Poor }\end{array}$ & 40.7 & 41.9 & 1.2 \\
\hline \multicolumn{8}{|c|}{ CENTRAL REGION } \\
\hline Poor & - & - & - & Poor & 53.4 & 54.7 & 1.3 \\
\hline $\begin{array}{l}\text { Extreme } \\
\text { Poor }\end{array}$ & & - & - & $\begin{array}{l}\text { Extreme } \\
\text { Poor }\end{array}$ & 36.7 & 38.3 & 1.6 \\
\hline
\end{tabular}


appears not to have any effect on poor as the impoverishing effect of health care payments increases before and after the policy the implemented. The pattern reverses for the extreme poor. The proportion of households classified as extreme poor as a result of payments for maternal delivery fell from 2.5 percentage points before the fee exemption policy to 1.3 percentage points after the fee exemption policy.

\section{Financing Maternal Delivery Care}

Table 8 shows financing of maternal delivery care by households. The mean share of out-of-pocket delivery payment in total household income declined after the policy of fee exemption for delivery care. The decline ranges from $13.18 \%$ for the poorest households ( $1^{\text {st }}$ quintile) to $21.51 \%$ in the richest households ( $5^{\text {th }}$ quintile). The middle income group ( $3^{\text {rd }}$ quintile) had a decline of $16.32 \%$.

Table 8 Mean Share of Out-of-Pocket Payment in Total Income

\begin{tabular}{|c|c|c|c|c|c|c|}
\hline \multirow{2}{*}{$\begin{array}{l}\text { Qui } \\
\text { ntil } \\
\text { e }\end{array}$} & \multicolumn{3}{|c|}{ Volta Region } & \multicolumn{3}{|c|}{$\begin{array}{l}\text { Combined (Volta and } \\
\text { Central Regions) }\end{array}$} \\
\hline & Before & After & Change & Before & After & Change \\
\hline 1 & 0.0506 & 0.0381 & -0.24704 & 0.0478 & 0.0415 & -0.1318 \\
\hline 2 & 0.0311 & 0.0245 & -0.21222 & 0.0327 & 0.0266 & -0.18654 \\
\hline 3 & 0.0308 & 0.0269 & -0.12662 & 0.0337 & 0.0282 & -0.1632 \\
\hline 4 & 0.0366 & 0.026 & -0.28962 & 0.0276 & 0.0294 & 0.065217 \\
\hline 5 & 0.0365 & 0.0246 & -0.32603 & 0.033 & 0.0259 & -0.21515 \\
\hline
\end{tabular}

\section{DISCUSSION}

Ghana has had a persistently high maternal mortality rate, growing social inequalities rates, and rates of skilled attendance being either stagnant or declining for poorer women. Financial barriers are one of the most important factors or constraints to seeking skilled care during deliveries. The fee exemption policy, may play a very important role in protecting households from making catastrophic payments for delivery care and consequently from falling into poverty.

The total costs of delivery to households are often determined by type and place of delivery. The type of delivery can be linked to the type of facility where delivery took place. Caesarean sections are always performed at the hospital (public, private or mission). Normal deliveries at health facilities can occur in a hospital (public, private or mission), health center or maternity homes. Home/TBA deliveries are usually assisted by traditional birth attendants, mother/mother-in-law, friends/neighbours or a health worker in the community. Caesarean section (c-section) is always performed by a medical doctor and normal deliveries at health facilities are by midwives/nurses.

Deliveries by c-sections increased after the implementation of the fee exemption policy for maternal delivery. As expected home/TBA deliveries fell during the same period. Normal deliveries at health facilities also fell after the exemption policy but this was not expected as we expect more mothers to take advantage of the policy.

Table 3 shows significant changes in the mean outof-pocket payment for delivery care (direct and indirect payments for delivery) at health facilities, both for spontaneous vaginal deliveries and delivery by c-sections. Although there was some change in mean out-of-pocket payment for delivery fee and total payment for delivery care for home/TBA births following the introduction of the fee exemption policy, this was not statistically significant.

The "catastrophic head count" for health care payments measures the extent to which a given sample of individuals has been exposed to catastrophic expenses. It is the proportion of individuals whose health care costs as a proportion of income exceed the threshold level. Generally, at lower thresholds, the incidence of "catastrophic" delivery payments is more concentrated amongst the poor, both before and after the exemption policy. In contrast at higher thresholds, the incidence of "catastrophic" delivery payments is more concentrated amongst the rich in both periods. Analysis of financing maternal delivery care shows that households in the richest quintile benefited more from the policy of fee exemption for delivery care (Table 8$)$.

\section{CONCLUSIONS AND POLICY REC- OMMENDATION}

There was a statistically significant decrease in the mean out-of-pocket payment for c-section and normal delivery at the health facility after the exemption policy. The share of mean households' out-of-pocket payment for delivery in total payment for delivery care declined after the exemption policy. A similar pattern was also observed in the mean share of delivery fee in total out-of-pocket payment for delivery.

In terms of financing maternal delivery care, households in the richest quintile benefited more 
from the fee exemption policy for delivery care than for poor households. The mean share of outof-pocket delivery payment in total household income declined from $13.18 \%$ for poor households ( $1^{\text {st }}$ quintile) to $21.51 \%$ in the rich households $\left(5^{\text {th }}\right.$ quintile).

The distribution of incidence of catastrophic outof-pocket payments shows a fall after the exemption policy. Generally, at lower thresholds, the incidence of catastrophic delivery payment is more concentrated amongst the poor before and after the exemption policy. In contrast, at high thresholds, the incidence of catastrophic delivery payments was more concentrated amongst the rich in both periods.

The fee exemption policy had a positive effect on the extreme poor than the poor. The proportion of households falling into extreme poverty (by poverty head count) as a result of payments for maternal delivery fell from 2.5 percentage points before the fee exemption policy to 1.3 percentage points after the policy.

Finally, in the implementation of such programmes in the future, the Government should have a clear definition of the poor. This will ensure proper targeting of the poor so that maximum impact is made at the end of the programme.

\section{ACKNOWLEDGEMENT}

This work was undertaken as part of an international research programme - Immpact (Initiative for Maternal Mortality Programme Assessment), funded by the Bill \& Melinda Gates Foundation, the Department for International Development, the European Commission and USAID. The funders have no responsibility for the information provided or views expressed in this paper. The views expressed herein are solely those of the authors. Thanks also go to all those who provided information and commented on earlier drafts of this paper.

\section{REFERENCES}

1. WHO. Revised 1990 Estimates of Maternal Mortality. WHO/FRH/MSM/96.11, UNICEF/PLN/96-1. April, 1996

2. Ministry of Health The Ghana Health Sector Annual Programme of Work, 2004. Ministry of Health Accra, Ghana. 2004a.

3. Ministry of Health, Guidelines for Implementing the Exemption Policy on Maternal Deliv- eries. Ministry of Health Accra, Ghana. October 2004b.

4. United Nations. The Millennium Development Goals Report.

www.un.org/millenniumgoals

5. http://www.safemotherhood.org/

6. Graham, W. Poverty and Maternal Mortality: What is the Link? Keynote Address Delivered at Annual Research Meeting, NMIMR, University of Ghana, Legon. 2004.

7. Nahar S and Costello A. The Hidden Cost of "Free" Maternity Care in Dhaka, Bangladesh. Health Policy and Planning 1998; 13(4): 417422.

8. Arhinful DK. The Solidarity of Self Interest: Social and Cultural Feasibility of Rural Health Insurance in Ghana. Leiden: Africa Studies Center 2003.

9. Nyonator F and Kutsin J, Health for Some? The effects of user fees in the Volta Region of Ghana. Health Policy and Planning 1999; 14(4): 329-341.

10. Commission on Macroeconomics and Health, Macroeconomics and Health: Investing in Health for Economic Development, Geneva. The World Health Organisation. Geneva 2001 .

11. Meessen B, Zhenzhong Z, Van Damme W, Devadasan N, Criel B, Bloom G. Iatrogenic poverty. Trop Med and Intl Health 2003; 8(7): 581-584.

12. WHO, The World Health Report 2000, Health Systems: Improving Performance. The World Health Organisation. Geneva 2000.

13. Borghi J, Hanson K, Acquah CA, Ekanmian G, Filippi V, Ronsmans C, Brugha R, Browne E, Alihonou E. Costs of Near-miss Obstetric Complications for Women and their Families in Benin and Ghana. Health Policy and Planning 2003; 18(4): 383-390.

14. Wagstaff, A. and van Doorslaer E. Catastrophe and Impoverishment in Paying for Health Care: With Applications to Vietnam, 1993-98. Health Econ 2003; 12(11): 921-934. 
